Reviews

ALAN SAMSON, until recently a journalism lecturer at Massey University, is a former colleague of El-Bendary and provided assistance in the production of his first book.

\section{Arab eyes on disliked 'ugly Americans'}

The 'Ugly American' in the Arab Mind: Why do Arabs resent America? Mohamed El-Bendary. Dulles: Potomac Books, 2011. 211 pp. ISBN 9781597976732

T IS not the place of this review to 1 make judgement on the rights and wrongs of what is going on in the Middle East. But it seems axiomatic that Western journalistic coverage of the region's conflicts can be little more than blinkered without a measured attempt to first make an effort to understand the depth and source of Arab feelings about the place of Israel and its perceived champion, the United States.

At a momentous time for the region, with upheavals from Bahrain to Egypt to Libya to Syria and beyond, Egyptian journalist and academic

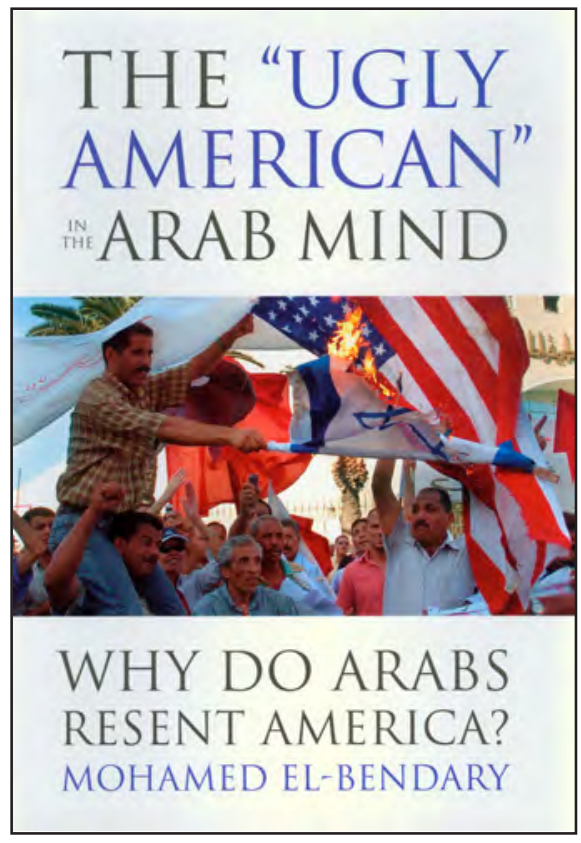

Mohamed El-Bendary has serendipitously made available a thorough research on Arab attitudes, as posited through the Arab press.

Early in his book, The 'Ugly American' in the Arab Mind, ElBendary concedes that most Arab media-working in 22 countries with a total population of 300 millionserve the interests of their governments. But whether on visits home from his academic placements in New Zealand and the United States, or his recent return to full-time residency in Benha, just north of Cairo, he has been uniquely placed to also chart the parallel mood of the people. The views are not out of kilter. 
El-Bendary's exercise in this book has been to impartially analyse the diverse Arab media to get a handle on why America is almost universally distrusted. The title phrase 'ugly American' is taken from the 1958 novel of that name by Eugene Burdick and William Lederer, an exposé of US ignorance, incompetence and corruption in the mythical country of Sarkhan - a clear parable to what was going on at the time in Vietnam.

El-Bendary's analysis, necessarily and correctly framed against the ever-backdrop of Israel and Palestine, concludes that American policy in the Middle East under the George W. Bush administration was 'haunted' by the same mistakes as the earlier US policy in South East Asia (p. 10).

His argument and analysis are well grounded. After an examination of the Arab media, his chapters-always through Arab eyes - discuss the view of American empire-building, the concept of American democracy, the so-called American 'dream', as well as, post-Bush, in what Arabs think of and expect from current US president Barack Obama.

The analysis, if carrying no great surprises, comes with plenty of meat. Among key Arab beliefs, is the view expressed by Al-Ahram correspondent Attif Al-Ghamri, that aggressive American foreign policies emanating from the White House will not end with Obama - that both Republicans and Democrats continue to believe democracy in the Arab world is the safeguard for national security in the US. Translation: Muslim terrorism is the enemy.

Interesting too, to hear the Arab view on Bush's 'war on terror speech', leading to the belief Bush was a greater threat to world peace than Saddam Hussein. 'While in Egypt, before and after Saddam's death, I heard many on the street speak of how Iraqis were better off under Saddam's rule,' El-Bendary writes. '[The press] often depicted the American president as a dictator and a narcissist' (p. 29). The cited Al-Bayan goes so far as to conclude that the Bush doctrine was little more than an extension of McCarthyism and the arms race with the former Soviet Union. The arrival [with Bush] of neoconservatives in Washington had revealed a hithertohidden colonial face. According to Al-Wafd, under the pretext of fighting terrorism, the "US hawks and neocons have put a plan to dominate "the five continents" and accomplish the “American project"' (p. 39).

The American project? This is the widely-held Arab belief (ElBendary cites here political scientist Said Al-Lawandi) that the Americans hold clear plans to reform the Middle 
East - as a matter of American security - by separating its past from its present. Journalist Attif Abdel Gawad is quoted doubting America's honesty in achieving peace. El-Bendary: 'The popular thought among Arabs is that American policy in the Middle East is founded on two major factors: controlling Arab oil (as seen in Iraq) and further empowering Israel and weakening the Palestinian cause. Arabs believe that for a just and durable peace to be established between them and the Israelis, the United States must play the role of an honest broker' (pp. 47-48).

Oil of course looms large. According to El-Bendary, Arabs see oil as a main factor behind US 'hostility' towards them, as well as for their invasion of Iraq, home of 11 percent of the world's reserves. The other main factor is the perception that US policy is in significant part driven by the desire to ensure the security of Israel.

Referring to 9/11, El-Bendary quotes an Egyptian cultural attaché as saying: 'Members of the US Congress saw no offense in supporting the neo-Israeli Nazism, which succeeded in convincing the American public to place the 9/11 terrorists and Palestinian mujahedeen in the same basket'. Arabs, El-Bendary says, believe that Israel is 'cashing in' on the widespread anti-Arab attitude engendered by the $9 / 11$ attacks (p. 58).

El-Bendary goes on to explore Arab thinking on why negative stereotypes of Arabs and Muslims exist in America. He links these not just to Bush's masterful PR phrase 'War on Terror', but also to Samuel Huntington's sombre 1993 warning of a 'clash of civilisations' post the Soviet era.

The negatives espoused in this book will be depressingly familiar to readers but will carry for many a powerful ring of truth. El-Bendary's analysis is lifted by a chapter entitled, 'What do Arabs want from Obama?' which traces the region's outpouring of hope at the election of the newblack-president.

Journalist Ahmed Ali wrote at the time: 'The entry of a 'black President' to the 'White House' is the biggest proof of American democracy (p. 119). Would that still be a prevailing view? An unavoidable weakness of El-Bendary's account relates to the speed in which the tumultuous events of the Middle East are proceeding. The reader of his meticulous account of Arab perceptions will want not only commentary of then, but of now.

The book does conclude with a postscript taking in the Arab Spring uprisings, but it is a pity these continuing events could not have been focal to the analysis.

Ultimately, however, this book 
deserves huge praise for the dispassionate nature of its analysis. It is not an anti-American rant, but a studied observation of beliefs widespread among 300 million Arabs.

Having said that, El-Bendary does not shy from making strong recommendations to Americans. They should not only end occupations but withdraw all military bases from the region, stop their promotion of dictatorial regimes, and remove home laws that discriminate against Arabs and Muslims. He also - with particular reference to Iraq-wants the US to link with educated Arabs to help instill a sense of hope for the future.

Sadly, one is left with the sure knowledge that road will remain a rocky one. El-Bendary notes Obama's efforts not to offend Islamic culture, as witnessed by the burial at sea of bin Laden 'in harmony with Islamic tradition'. But in the best traditions of the Ugly American he even got that wrong. As Dubai's Grand Mufti Mohammed Al-Qubaisi put it: 'Sea burials are permissible for Muslims in extraordinary circumstances. This is not one of them' (p. 161).

El-Bendary concludes: 'My advice to US policy-makers is to assist but keep a distance, guide but not lead, help but without being driven by a capitalist desire to gain something in return. They should also continue working diligently toward finding a solution to the stalled Middle East peace process-one that ensures the establishment of an independent Palestinian state with East Jerusalem as its capital.

'America and Americans will then truly be the "friends" of the Arabs, and we will see an inching toward true reconciliation between the state of Israel and the state of Palestine, between Arabs and Israelis - among Muslims, Christians, and Jews - rather than these never-ending carnivals of peace and the thirty-second video clips of handshakes and signatures on dotted lines' (pp. 162-163).

It's a lovely thought. In earlier recommendations, El-Bendary also urges American scholars to study Arabian history and politics, "not through their own prism but by travelling, living, and indulging in Arab cultures' (p. 149).

In his book The Great War for Civilisation, British foreign correspondent Robert Fisk similarly suggests that all journalists venturing into the region should carry a history book in their back pockets. A copy of El-Bendary's book might not go amiss, either. 


\section{References}

El-Bendary, M. (2010). The Egyptian press and coverage of local and international events.Lanham: Lexington Books.

Fisk, R. (2005). The great war for civilisation: The conquest of the Middle East. London: Fourth Estate.

Lederer, W. J., and Burdick, E. (1999). The ugly American. (New issue).New York: W.W. Norton.

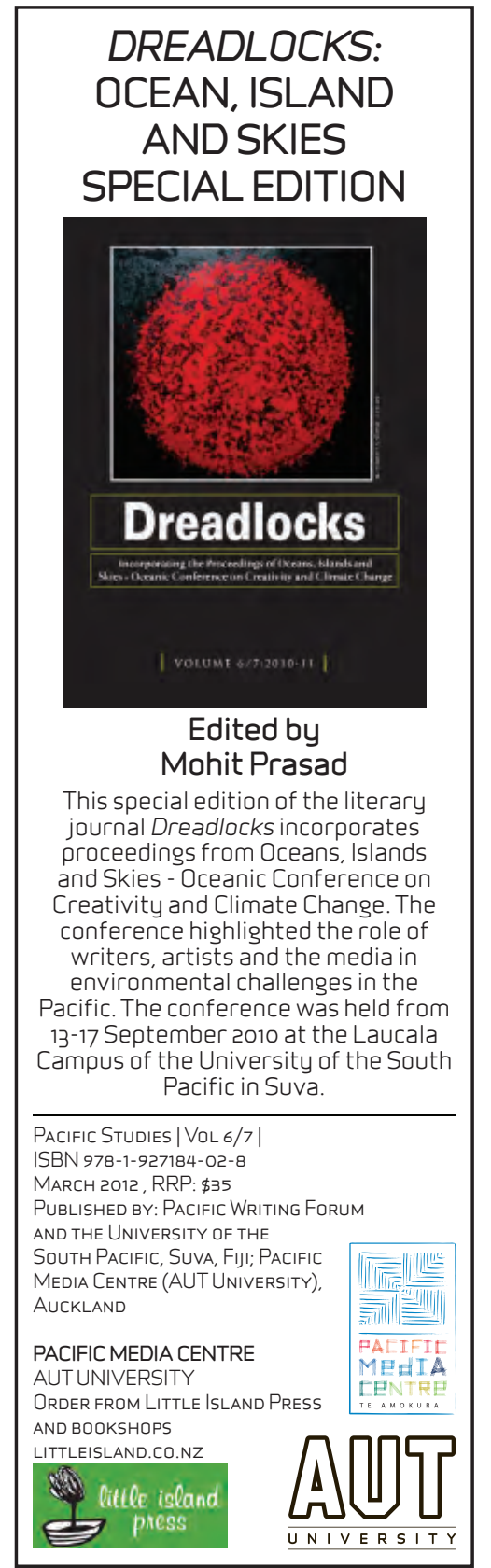

PACIFIC JOURNALISM REVIEW 18 (1) 2012221 